\title{
A NETNOGRAPHIC STUDY OF ENTREPRENEURIAL TRAITS: EVALUATING CLASSIC TYPOLOGIES USING THE CROWDSOURCING ALGORITHM OF AN ONLINE COMMUNITY
}

Marcos Cerqueira Lima De Vinci Business Lab, PULV, Paris, France

E-mail: marcos.cerqueira_lima@devinci.fr

Laila Namaci

De Vinci Business Lab, PULV, Paris, France

E-mail: laila.namaci@devinci.fr

Thierry Fabiani

De Vinci Business Lab, PULV, Paris, France

E-mail: thierry.fabiani@devinci.fr

Submission: $26 / 11 / 2013$

Revision: 22/01/2014

Accept: 27/01/2014

\section{8?}

\section{ABSTRACT}

This paper evaluates how the advices of experienced entrepreneurs to young start-up creators in an online community reflect entrepreneurship traits commonly found in conceptual typologies. The overall goal is to contrast and evaluate existing models based on evidence from an online community. This should facilitate future studies to improve current typologies by ranking entrepreneurial traits according to perceived relevance. In order to achieve these objectives, we have conducted a "netnographic study" (i.e., the qualitative analysis of webbased content) of 96 answers to the question "What is the best advice for a young, first-time startup CEO?" on Quora.com. Relying on Quora's ranking algorithm (based on crowdsourcing of votes and community prestige), we focused on the top $50 \%$ of answers (which we shall call the "above Quora 50" category) considered the most relevant by its $2000+$ followers and $120,000+$ viewers. We used Nvivo as a Qualitative Data Analysis Software to code all the entries into the literature categories. These codes were then later retrieved using matrix queries to compare the incidence of traits and the perceived 
INDEPENDENT JOURNAL OF MANAGEMENT \& PRODUCTION (IJM\&P)

http://www.ijmp.jor.br

v. 5, n. 3, June - September 2014

ISSN: 2236-269X

DOI: 10.14807/ijmp.v5i3.171

relevance of answers. We found that among the 50\% highest ranking answers on Quora, the following traits are perceived as the most important for young entrepreneurs to develop: management style, attitude in interpersonal relations, vision, self-concept, leadership style, marketing, market and customer knowledge, innovation, technical knowledge and skills, attitude to growth, ability to adapt, purpose and relations system. These results could lead to improving existing typologies and creating new models capable of better identifying people with the highest potential to succeed in new venture creation.

Keywords: Entrepreneur traits, entrepreneurship typologies, online communities, netnography, Web 2.0 ranking algorithms, crowdsourcing

\section{INTRODUCTION}

This paper looks at the qualitative analysis of the contents in an online community discussion around the topic of ideal entrepreneurship traits. The idea is to contrast these community perceptions with traits commonly found in conceptual typologies. It has a triple objective: a) to identify entrepreneurship traits and attributes from the literature review that are highly important in the perception of actual entrepreneurs in the online community; b) to establish literature traits and attributes that are considered less important $c$ ) to identify emergent characteristics that are present in the community data but are not often mentioned in the typologies considered. The overall goal is to contrast and evaluate existing models based on evidence from the online community. This should facilitate future studies to improve existing typologies by ranking entrepreneurial traits according to perceived relevance.

In order to achieve these objectives, we have conducted a passive or observational "netnographic study" (KOZINETS, 2010), consisting in the qualitative analysis of an online community answers to the question "What is the best advice for a young, first-time startup CEO?" on Quora.com. Quora is a forum in which experts in a given domain offer their insights based on public queries. Relying on Quora's ranking algorithm (based on crowdsourcing of votes and community prestige), we focused on the top $50 \%$ of answers considered the most relevant by its $2000+$ followers and 120,000+ viewers. We shall call this the "above Quora 50" category. We contrasted the most commonly mentioned traits in this category with a list of 
INDEPENDENT JOURNAL OF MANAGEMENT \& PRODUCTION (IJM\&P)

DOI: 10.14807/ijmp.v5i3.171

general entrepreneur characteristics according to the typologies described in the literature review.

This article is divided in four sessions. In the first we conduct a literature review of common entrepreneur typologies and the traits and attributes associated with them. We then describe the empirical approach used to analyze Quora's contents. We then present the main findings and discuss them, then conclude by pointing out limitations of this exploratory study and by suggesting future developments in this field.

\section{LITERATURE REVIEW}

Three approaches can be identified in the literature of entrepreneurship typologies: the entrepreneurs, their actions and the context in which they operate. These are respectively treated as the cognitive, structural and praxeological approaches (VERSTRAETE, 2002; VERSTRAETE, et al., 2011). That is consistent with the notion that the phenomenon of entrepreneurship revolves around the entrepreneur (the individual, their traits), the organization (the new venture) and the relationship between the two (JULIEN; MARCHESNAY, 1996; BRUYAT, 1993; OMRANE, et al., 2011). In this review, we are going to focus on the individual (the so-called "traits approach", mostly based on cognitive and psychological characteristics) and the attributes of the entrepreneurship process (the "process approach", which can be regarded as a synthesis between the structural and praxeological approaches).

The individual approach emphasizes entrepreneurial traits and what sets them apart from the rest of the population. It addresses the question "who is the entrepreneur and why do they create new ventures?" This approach is often one of the main components of entrepreneurship typologies (FILION, 2000). It has been severely criticized (GARTNER, 1988) for being incomplete and not taking into account the interactive nature of the entrepreneurship process.

The process approach emphasizes the relationship between the environment, the organization and the entrepreneur. Less easily identifiable because of its dynamic nature, it is usually detected indirectly in the typological treatments of the entrepreneurship phenomenon. The following sessions will take a closer look at both traditions. 


\subsection{The Individual Traits Approach}

As previously stated, early research in entrepreneurship focused primarily on the characteristics of new venture creators and, more specifically, their personality traits. They focused on the psychological aspect of the individual, trying to address questions such as: "Why under similar circumstances some individuals decide to start their own business, while others were do not?" or "is the entrepreneurial character innate or acquired?" (GARTNER, 1989; HO; BARNES, 2012).

Among the most commonly researched traits found in the literature, we can cite:

- The need for achievement: the work of McClelland (1961, 1965, 1969 cited by HERNANDEZ, 1999) popularized this concept and contributed to its development. According to this author, entrepreneurs are primarily motivated by their drive to accomplish their vision. They see themselves as masters of their fate, so they seek responsibility for the planning and execution of their unique endeavors.

- The internal locus of control: it is the perception, closely related to the previous trait, that an individual can control what is happening internally. In other words, these individuals feel that they can influence what happens to them by their behavior. Various studies (FILION, 2000) have shown that the new venture creators have an internal locus of control as the source to their actions.

- The propensity to take risks: starting a business is an adventure full of risks. According to Belley (1990, cited by HERNANDEZ, 1999) these risks are of different natures: financial, psychological, business related and family related.

This school of thought has been quite strongly criticized. Critics of the "traits approach" rightly point out that a great number of individuals with similar personality traits never chose to start a new venture and instead preferred more traditional careers. The legacy of this research tradition remains highly controversial, as it has failed to produce traits that would be necessary and sufficient conditions to distinguish between venture creating profiles and non-entrepreneurial types. These 
DOI: 10.14807/ijmp.v5i3.171

studies are characterized by their one-dimensional approach of the entrepreneurial phenomenon, and clearly overlook the role of the environment in this phenomenon.

\subsection{The Process Approach}

A more holistic approach has emerged in the past two decades. This perspective emphasizes that entrepreneurial behaviors are not the result of individual or contextual determinism, but of a strategic intent of specific actors under specific circumstances (BERNOUX, 1990; AMBLARD, et al., 1996; FAYOLLE, 2001; MOROZ; HINDLE, 2012). The entrepreneur is seen as someone who reasons and calculates who evaluates the means they need to achieve certain ends. This selfawareness would explain their actions and, in particular, their professional behavior. This behavior is entirely conditioned by the situation in which they find themselves.

Hence, the entrepreneurial process involves several environmental variables (social, economic, cultural, and organizational). It is proactively driven by the activities and actions of certain individuals that decide to transform opportunities into new ventures (BYGRAVE; HOFER, 1991, cited by FAYOLLE, 2002). The entrepreneurial process combines behavioral descriptions and organizational contexts into complex, dynamic models. For Hernandez (1999), this approach requires a good understanding of organizational theory and particularly the notion "organizational emergence".

As an early example of this tradition, Shapero (1975) discusses four main variables to explain the act of creating new ventures: contextual, psychological (motivation, attitude, etc.), sociological (family, peer group, etc.), economic (availability of resources, economic opportunities and threats, etc.). Several authors have been inspired by Shapero's model. We note for example the framework by Le Marois (1985), which is structured around three poles: relational, personal and professional.

\subsection{Filion's Synthesis}

Over a decade ago, Louis Jacques Filion (2000) undertook a comprehensive study of the criteria commonly used to develop entrepreneurial typologies. He started with the very first typologies developed by Arthur H. Cole $(1942,1946)$, a field pioneer who established the Entrepreneurship Center at Harvard University with Joseph Schumpeter in the late 1940s. He then looked at the typologies created by 
Smith (1967), Collins and Moore (1970), Laufer (1975), Miles and Snow (1978), Vesper (1980), Julien and Marchesnay (1987), Carland et al. (1988), Lafuente and Salas (1989), his own typology Filion (1998) and Marchesnay's (1998). Based on this collection of typologies, Filion (2000) came up with the following list of criteria most commonly used to develop entrepreneurial typologies:

Table 1: Filion's synthesis of common entrepreneurship traits

\begin{tabular}{|l|l|}
\hline 01. Self-concept & 13. Need for achievement \\
\hline 02. Commitment & 14. Need for power \\
\hline 03. Systemic root & 15. Need for recognition \\
\hline 04. Vision & 16. Need for security \\
\hline 05. Relations system & 17. Attitude to growth \\
\hline 06. Delegation & 18. Attitude in interpersonal relations \\
\hline 07. Purpose & 19. Attitude to profits \\
\hline 08. Independence & 20. Attitude to risk \\
\hline 09. Locus of control & 21. Leadership style \\
\hline 10. Ability to adapt & 22. Management style \\
\hline 11. Creativity & 23. Decision-making style \\
\hline 12. Innovation & 24. Strategic style \\
\hline
\end{tabular}

This synthesis is clearly biased towards the "individual traits" approach, lacking the dynamic, interactive elements of the "process approach". It is centered on cognitive and psychological traits rather than contextual, sociological or organizational variables and is therefore incomplete as a tool for understanding the entrepreneurship phenomenon. However, for our purposes of exploring which traits are perceived to be the most relevant in the entrepreneur's personality, Filion's synthesis is a good starting point.

As the following empirical session will show, the above list overlooks at least two characteristics perceived to be quite important by the Quora community: "Marketing, Market and Customer Knowledge" and "Technical Knowledge". Those are not "psychological traits" as most of the variables in Filion's list, of course, but rather closer to the "process approach", indicating how well prepared entrepreneurs are to deal with their organizational and socio-economic environment. Therefore, these two high ranking variables that emerged from the Quora data seem to suggest that this online community is quite aware of the limits of the "individual traits" approach. More interestingly for the purposes of this paper, they seem to suggest that "Marketing, Market and Customer Knowledge" is perceived as one of the most important characteristics of successful entrepreneurs. 
INDEPENDENT JOURNAL OF MANAGEMENT \& PRODUCTION (IJM\&P)

http://www.ijmp.jor.br

v. 5, n. 3, June - September 2014

ISSN: 2236-269X

DOI: 10.14807/ijmp.v5i3.171

\section{METHODS}

The objective of this study was to confront Filion's synthesis of entrepreneur traits with the perceptions of Quora.com online community members who answered the question "What is the best advice for a young, first-time startup CEO?" It was assumed that by "young, first-time start-up CEO" the community had in mind an entrepreneur who founded the new venture, as is usually the case in small businesses. The vast majority of the verbatim statements by community members confirm this assumption.

The chosen method was the passive or observational ethnographic study (KOZINETS, 2010). This is a more superficial, non-immersive version of the fullblown netnography approach, which Kozinetz (2010, p. 60) defines as a "participantobservational research based in online fieldwork. It uses computer-mediated communications as a source of data to arrive at the ethnographic understanding and representation of a cultural or communal phenomenon". In an earlier work, Kozinets (2002, p. 61) argues that this technique uses "information publicly available in online forums to identify and understand the needs and decision influences of relevant online consumer groups". Originally designed by marketers to understand consumer behavior, it can be adapted to understand online community perceptions in general. It is less time consuming and elaborate than traditional qualitative methods such as focus groups and interviews besides being more timely, less costly and less obtrusive (KOZINETS, 2002). It is based on the observation of textual discourse, not of the individuals themselves. Informants in netnography therefore "may be presumed to be presenting a more carefully cultivated and controlled self-image" ( $p$. $68)$.

Kozinets $(2002,2010)$ defines the following six stages for a full-blown netnography: (1) making cultural entrée, (2) gathering and analyzing data, (3) ensuring trustworthy interpretation, (5) conducting ethical research, and (6) providing opportunities for culture member feedback. Being the present study a "passive" version of that method without direct participation of the researchers in the communities, phases 1 and 6 are not as relevant. This exploratory investigation sometimes called a "netnographic exploration" (see PERKINS, 2010) does not have therefore any ambition of obtaining the in-depth insights offered by the participant immersion in an online community over an extended period of time, such as 
INDEPENDENT JOURNAL OF MANAGEMENT \& PRODUCTION (IJM\&P)

DOI: 10.14807/ijmp.v5i3.171

proposed by the original netnography approach. Similar non-participative, "passive ethnographic" explorations have been undertaken recently by several authors (BEAVEN; LAWS, 2007) and by Kozinets himself (BROWN; SHERRY; KOZINETS, 2007).

Out of the 102 answers available in the community in February 2013, 96 were considered "valid" ( 6 off-topic answers were eliminated by community members). These answers were contributed over a period of over three years since the question was first formulated. The following statistics give an idea about the respondent's profile: $90 \%$ are male and $60 \%$ declare themselves to be either founders or CEOs of start-up themselves; among the $60 \%$ of respondents whose location was known, the vast majority live in the US (50\%), followed by India (15\%), the UK (10\%) and Canada $(8 \%)$, which reflect the native English-speaking bias of the community members.

Quora became one of the most popular question-and-answer services on the web due to the efficiency of its answer-ranking algorithm. Using a combination of a public voting system with community reputation scores, it makes sure that the most relevant contributions will emerge to the top. We'll call "Quora Relevance" (QR) the position of an answer relative to the others according to Quora's ranking algorithm. Note that answers with a very high number of votes can be ranked lower than a contribution with less votes; community prestige and the quality of previous answers sometimes are more important in Quora's algorithm than the mere number of votes.

Figure 1 shows the number of votes received by answers in four categories: $75-100 \%$ QR (the top 24 answers, which we will call "Quora 100"), 50-75\% QR (the 24 answers that follow, "Quora 75"), 25-50\% QR and 1-25\% (the 50 lowest ranking answers, respectively "Quora 50" and "Quora 25").

As indicated by the above Figure, only 3 "nodes" (answers) in the "Quora 100" tier had 5 votes or less. That proportion jumps to $70 \%$ in "Quora 75 " and over $90 \%$ in the "Quora 50"and "Quora 25" tiers. We had the choice of focusing only on the top $25 \%$ or using the "above Quora 50" cutting point (half the total number of answers). We decided for the latter option, in spite of the high number of questions with few votes in the "Quora 75" category. We did this because, as explained previously, the number of votes is only one of the criteria used by Quora's algorithm to rank the relevance of an answer. The fact that an answer is in the "better half" of the list 
DOI: 10.14807/ijmp.v5i3.171

means it is considered much more relevant than an answer with a similar number of votes which are ranked lower. Therefore, all answers "above Quora 50" were deemed relevant.

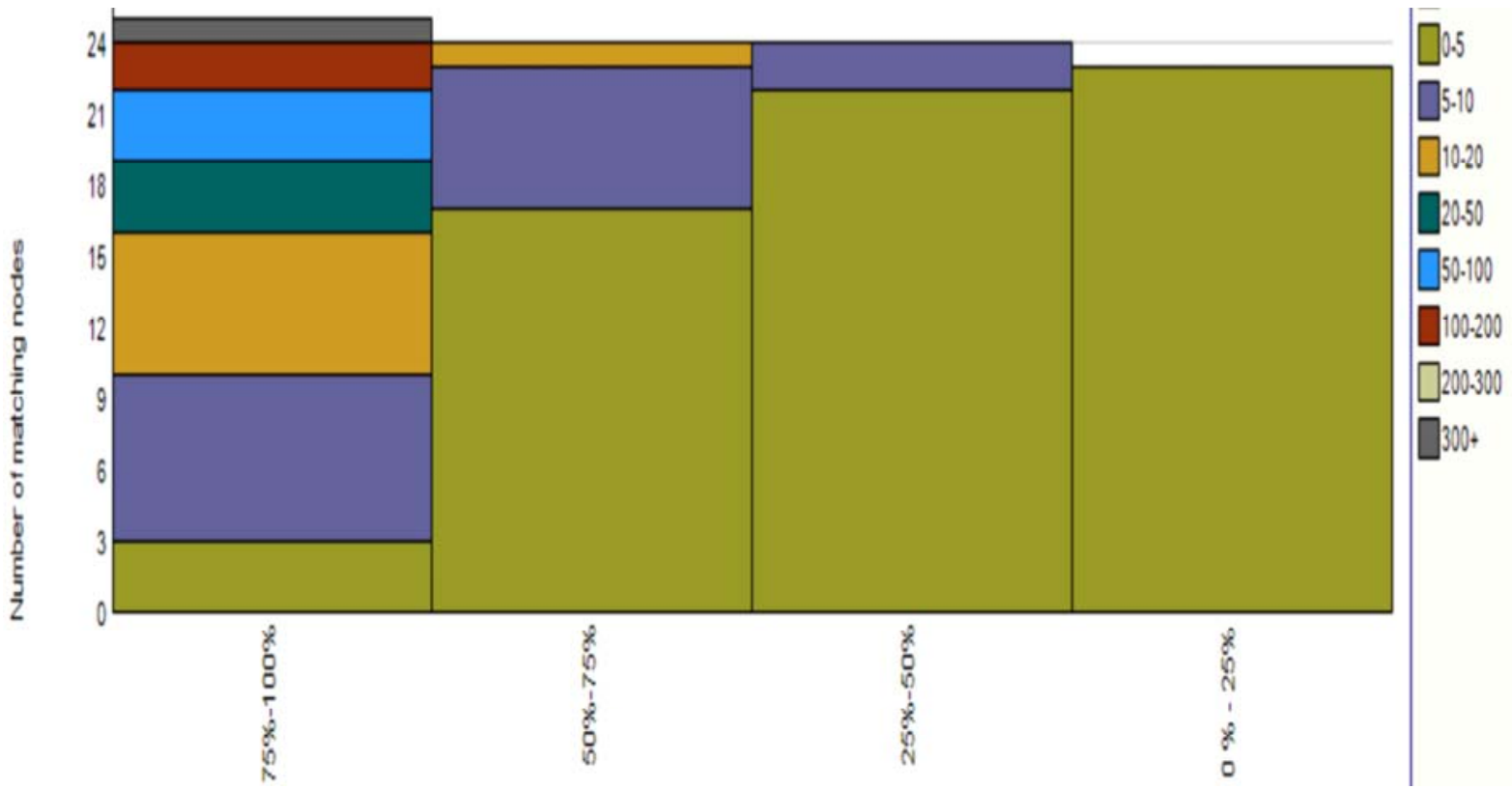

Figure 1: Number of Votes in Four Levels of "Quora Relevance"

We used Nvivo 10 as Qualitative Data Analysis Software to code fragments of the answers into the categories of Filion's synthesis. Cross-coding was used among the authors to ensure consistency. When a Quora statement didn't seem to fit any of Filion's variables, new categories or "nodes" were created. These 9 new "emergent variables" are listed below:

Table 2: Entrepreneur characteristics emerging from the Quora data which were not listed by Filion

\begin{tabular}{|l|l|}
\hline 25. Marketing, Market and Customer Knowledge & 30. Patience \\
\hline 26. Lifestyle & 31. Communication Skills \\
\hline 27. Technical Knowledge and Skills & 32. Attitude Towards Failure \\
\hline 28. Ethics & 33. Ability to Learn \\
\hline 29. Reputation Management & \\
\hline
\end{tabular}

The frequency with which these nodes appeared in the Quora community was then retrieved using matrix queries with NVivo. The top 12 results are presented on Table 1 below. 
Table 3: Top 12 entrepreneur traits ranked above "Quora 50" (asterisks indicate

\begin{tabular}{|c|c|c|c|c|}
\hline 122 : Management style & 19 & 3 & 22 & 28 \\
\hline 218 : Attitude in interpersonal relations & 8 & 4 & 12 & 24 \\
\hline 304 : Vision & 7 & 4 & 11 & 19 \\
\hline 401 : Self-concept & 8 & 2 & 10 & 22 \\
\hline 521 : Leadership style & 6 & 3 & 9 & 16 \\
\hline \begin{tabular}{l|l}
625 : Marketing, Market \& Customer Knowledge*
\end{tabular} & 2 & 6 & 8 & 9 \\
\hline 712 : Innovation & 4 & 2 & 6 & 13 \\
\hline 827 : Technical Knowledge and Skills* & 2 & 4 & 6 & 9 \\
\hline 917 : Attitude to growth & 3 & 2 & 5 & 11 \\
\hline 1010 : Ability to adapt & 1 & 4 & 5 & 9 \\
\hline 1107 : Purpose & 4 & 1 & 5 & 8 \\
\hline 1205 : Relations system & 2 & 2 & 4 & 10 \\
\hline
\end{tabular}

\section{FINDINGS AND DISCUSSION}

It is perhaps unsurprising that "management style" emerged as the top characteristic; the term is so vague that it can encompass several of the "process approach" variables related with organizational and environmental contexts. By breaking down this category into sub-categories (Table 4), we found that the vast majority of comments (64\%) were related with hiring and firing practices. Peter Berg (whose answer was ranked number one by far with astounding 320 votes!) for example advises young entrepreneurs to "Be really picky with your hiring, and hire the absolute best people you possibly can". The comment "Hire people smarter than you" by Adrian Aoun was the only sentence he contributed to the discussion; it earned him 82 votes. Mark Otero had 186 votes with the comment "Hire for passion: Hire for passion over experience. When you can afford it, hire employees who have both". Eleven other "Quora 100" answers had similar recommendations.

The other components of "Management Style" recommendations were "Structure and Governance" (comments such as "build a great board and/or advisory board" by Jared Kim, 52 votes), "Processes" ("Trust your team but constantly measure them on goal" by Paul Singh, 13 votes) and "Culture" (one single comment by Chris Prescott, "Build the company culture around achievement and momentum and the rest will generally fall into place", 17 votes). 
ISSN: 2236-269X

DOI: 10.14807/ijmp.v5i3.171

Table 4: Breaking down of the "Management Style" category into its sub-nodes

\begin{tabular}{l|c|c|c|r|} 
& $\begin{array}{c}\text { a. } \\
\text { Quora 100 }\end{array}$ & $\begin{array}{c}\text { b. } \\
\text { Quora 75 }\end{array}$ & $\begin{array}{c}\text { Above Quora 50 } \\
(\mathrm{a}+\mathrm{b})\end{array}$ & \multicolumn{2}{c|}{$\%$} \\
\hline Hiring and Firing & 11 & 3 & 14 & $64 \%$ \\
\hline Structure and Governance & 4 & 0 & 4 & $18 \%$ \\
\hline Processes & 3 & 0 & 3 & $14 \%$ \\
\hline Culture & 1 & 0 & 1 & $100 \%$ \\
\hline Total for "Management Style" & 19 & 3 & 22 & \\
\hline
\end{tabular}

For the sake of synthesis, Table 5 reproduces some of the representative comments for each one of the other 11 top ranking traits above.

Table 5: Sample comments for top ranking entrepreneur traits on the online community at Quora.com

\begin{tabular}{|c|c|c|c|}
\hline \# & Trait & $\begin{array}{l}\text { Above- } \\
\text { Q50 } \\
\text { Incidents }\end{array}$ & $\begin{array}{l}\text { Sample Comments (numbers in parenthesis = votes on Quora; } \\
\text { comments are presented in decreasing order of relevance) }\end{array}$ \\
\hline 2 & $\begin{array}{l}\text { Attitude in } \\
\text { interpersona } \\
\text { I relations }\end{array}$ & 12 & $\begin{array}{l}\text { "Find a couple trusted, experienced advisors/mentors" (320), "When } \\
\text { fundraising, ask people for advice, not money" (320), "Share, don't be } \\
\text { afraid that others will go out and copy your business" (29), "Don't be } \\
\text { afraid to have tough conversations" (8), "Being actively social (in the } \\
\text { real world, too!)" (8), "Trust your co-founders" (10) }\end{array}$ \\
\hline 3 & Vision & 11 & $\begin{array}{l}\text { "you're responsible for steering the vision of the company, including } \\
\text { setting long-term goals for your eventual total world domination" (320), } \\
\text { "Focus Sounds simple, but probably the best bit of advice I've } \\
\text { received so far" (17), "Learn to Say No In the early months" (17), "Find } \\
\text { a co-founder who shares your vision" (14) }\end{array}$ \\
\hline 4 & Self-concept & 10 & $\begin{array}{l}\text { "Know your weaknesses" (187), "Stay Humble, Stay Positive" (17), } \\
\text { "the best answer I can give you is not to call yourself a CEO" (9), "Be } \\
\text { honest to yourself" (14), "consider removing your tear ducts" (8). }\end{array}$ \\
\hline 5 & $\begin{array}{l}\text { Leadership } \\
\text { style }\end{array}$ & 9 & $\begin{array}{l}\text { "Communicate and be transparent with your team" (52), "Eat with your } \\
\text { team often" (21), "Find someone who disagrees with you often to be in } \\
\text { your think tank" (8), "have an inventory of your team's strengths and } \\
\text { weaknesses. their attitudes and personalities" (6) }\end{array}$ \\
\hline 6 & $\begin{array}{l}\text { Marketing, } \\
\text { Market \& } \\
\text { Customer } \\
\text { Knowledge* }\end{array}$ & 8 & $\begin{array}{l}\text { "Go to industry-specific events" (186), "The most important thing is to } \\
\text { understand what constitutes value to your customers" (9), "Read a lot } \\
\text { about your market and talk to smart people" (4), "Learning by doing } \\
\text { including things like: - constantly talking to people - listening to } \\
\text { customers" (7), "Know your market - research, ask, be mentored, be a } \\
\text { sponge of data about your market" (6) }\end{array}$ \\
\hline 7 & Innovation & 6 & $\begin{array}{l}\text { "Fail fast: start with a working set of assumptions and test them out in } \\
\text { the market very fast" (186), "Get *someone* to pay you to test } \\
\text { product/market fit" (135), "Without the right product, you're building } \\
\text { your house on sand with no foundation and everything else will fall } \\
\text { apart" (17), "Keep your idea/product/feature simple and gradually } \\
\text { expand" (6), "Try it fast with little money. Make adjustments" (3) }\end{array}$ \\
\hline 8 & $\begin{array}{l}\text { Technical } \\
\text { Knowledge } \\
\text { and Skills* }\end{array}$ & 6 & $\begin{array}{l}\text { "Learn how to set up and run the hell out of an Amazon Mechanical } \\
\text { Turk, Google Analytics, etc. now" (135), "Read up on what successful } \\
\text { and smart people have written about the topic" (7), "Know your } \\
\text { financials - burn rate, capital, expenditures, etc." (6), "Do something } \\
\text { within your area of expertise" (5), "Learn how to sell or find a partner } \\
\text { that can" (5) }\end{array}$ \\
\hline
\end{tabular}


DOI: 10.14807/ijmp.v5i3.171

\begin{tabular}{|l|l|c|l|l|}
9 & $\begin{array}{l}\text { Attitude to } \\
\text { growth }\end{array}$ & 5 & $\begin{array}{l}\text { "Don't give away equity too easily" (320), "don't be a startup, be a } \\
\text { business" (47), "50\% of a successful company is better than 100\% of } \\
\text { a failure" (8), "Always raise more capital than you think you need" (0). }\end{array}$ \\
\hline 10 & $\begin{array}{l}\text { Ability to } \\
\text { adapt }\end{array}$ & 5 & $\begin{array}{l}\text { "Get used to feeling not good enough" (135), "Dont waste time in the } \\
\text { pursuit of perfection" (4), "Learn to quickly balance pros and cons" (6), } \\
\text { "Do everything that makes sense to you but be aware of red flags and } \\
\text { remain resilient to change" (5) }\end{array}$ \\
\hline 11 & Purpose & 5 & $\begin{array}{l}\text { "Be obsessed with your idea" (135), "Catalog a list of hobbies you'll } \\
\text { take up 'when you make it" (135), "Build your company, product \& } \\
\text { culture with intention" (8), "The intentional mind leaves no one behind } \\
\text { - that is the true code of an entrepreneur" (8) }\end{array}$ \\
\hline 12 & $\begin{array}{l}\text { "Your choice of partners and investors should be thought of as } \\
\text { permanent and are therefore the most important two decisions you } \\
\text { make." (73), "Just pick up the phone, I want to stress that with a few } \\
\text { exceptions almost no one is out of reach these days." (29), "Have your } \\
\text { cheerleaders (friends/family/supporters) on speed dial" (5) }\end{array}$ \\
\hline system & 4 &
\end{tabular}

Special attention should be given to the so-called "emerging categories": Marketing, Market and Customer Knowledge (ranked $6^{\text {th }}$ ) and Technical Knowledge and Skills (ranked $8^{\text {th }}$ ). Filion seemed to be quite focused on limiting his choice of variables to the cognitive / psychological traits of the "individual approach" when he created his synthesis, otherwise he would have added these two components which are an inherent part of his own "visionary process" (Filion, 1991) framework. Most of the other elements of his model (vision, leadership style, self-concept, relations system) are present in his synthesis and have actually ranked quite high in our Quora study.

It is a testament to the so-called "wisdom of the crowds" (as Web 2.0 crowdsourcing is often called) that these two components emerged from the Quora data to enrich Filion's synthesis. This confirms the need to go beyond the "individual traits" approach and to embrace more complex -- albeit difficult to measure -variables inherent to the "process approach".

Finally, it is necessary to look at the attributes that scored extremely low in this study and speculate why that was the case. Table 6 presents the Quora ranks from the $13^{\text {th }}$ to the $33^{\text {rd }}$ positions.

Table 6: Lower ranking entrepreneur traits on the online community at Quora.com 


\begin{tabular}{|c|c|c|c|c|c|}
\hline 13 & Strategic style & 3 & 1 & 4 & 6 \\
\hline 14 & Lifestyle* & 4 & 0 & 4 & 5 \\
\hline 15 & Commitment & 2 & 1 & 3 & 8 \\
\hline 16 & Patience* & 2 & 1 & 3 & 6 \\
\hline 17 & Delegation & 2 & 1 & 3 & 5 \\
\hline 18 & Attitude to profits & 1 & 2 & 3 & 4 \\
\hline 19 & Creativity & 2 & 1 & 3 & 3 \\
\hline 20 & Ethics* & 0 & 2 & 2 & 6 \\
\hline 21 & Attitude to Failure* & 0 & 2 & 2 & 6 \\
\hline 22 & Attitude to risk & 2 & 0 & 2 & 4 \\
\hline 23 & Need for recognition & 2 & 0 & 2 & 2 \\
\hline 24 & Need for security & 2 & 0 & 2 & 2 \\
\hline 25 & Decision-making style & 1 & 1 & 2 & 2 \\
\hline 26 & Reputation Management* & 1 & 0 & 1 & 9 \\
\hline 27 & Ability to learn* & 0 & 1 & 1 & 8 \\
\hline 28 & Communication Skills* & 0 & 1 & 1 & 7 \\
\hline 29 & Independence & 1 & 0 & 1 & 4 \\
\hline 30 & Systemic root & 1 & 0 & 1 & 3 \\
\hline 31 & Locus of control & 0 & 1 & 1 & 2 \\
\hline 32 & Need for achievement & 1 & 0 & 1 & 2 \\
\hline 33 & Need for power & 0 & 0 & 0 & 0 \\
\hline
\end{tabular}

Among the least important characteristics (in the bottom five positions) we found the following: independence, systemic thinking, locus of control, need for achievement and need for power. We believe that the very low score of these traits is related to the way the original question was formulated: "What is the best advice for a young, first-time startup CEO?..." Very few people would advise young entrepreneurs to seek power or even achievement for achievement's sake. Systemic thinking and locus of control are very abstract concepts, difficult to formulate as an advice.

Among the "emerging traits" that were seldom mentioned in the literature review but were considered highly relevant in the "above Quora 50" category, we found: good lifestyle habits, patience and ethics. These could be valuable additions to Filion's synthesis. Traits like reputation management, ability to learn and communication skills had surprisingly low scores in the same category (they ranked much better in "Quora 100", which includes all 96 respondents and not just the 50\% most relevant). 
INDEPENDENT JOURNAL OF MANAGEMENT \& PRODUCTION (IJM\&P) http://www.ijmp.jor.br

v. 5, n. 3, June - September 2014 ISSN: 2236-269X

DOI: 10.14807/ijmp.v5i3.171

\section{CONCLUSIONS AND RECOMMENDATIONS}

This is clearly an exploratory study based on a small sample of users of an online questions and answers service and therefore its findings cannot be generalized. It needs to be followed up by quantitative studies based on a representative sample in order to allow for generalizations. Furthermore, it is based on a specific question about advice to be given to young start-up creators and managers, and hence has a bias towards the positive qualities we expect these people to develop. Classic traits found in the literature, such as the need for achievement and the need for power are therefore ranked understandably low in the perception of the "advisers".

The preliminary implications of our findings are manifold: a) as well as finding "common traits" in existing typologies, researchers should also seek to rank them according to the perceived importance in the eyes of experienced entrepreneurs; $b$ ) young entrepreneurs may be overwhelmed with hundreds of "best practice" advices found in both academic and professional publications; giving them a sense of what skills and traits to prioritize in their development may help them focus on the attributes that are perceived by a large community of practice to be the most relevant; c) teachers and researchers of entrepreneurship may acquire a more nuanced view of entrepreneur traits perceived as relevant. This could lead to improving existing typologies and creating new models capable of better identifying people with the highest potential to succeed in new venture creation.

Online communities such as Quora and their "relevant content algorithms" are becoming increasingly meaningful as a resource for understanding how certain groups feel about specific issues; one must be reminded that behind the $50 \%$ most relevant answers used in our ranking system there are the "voices" of thousands of users who voted them up and down in Quora's relevance hierarchy during a period of more than 36 months. Even if online communities have been a major source of qualitative research insights in the recent past, the collaborative nature of Web 2.0 "crowdsourcing" technologies, which evolved in the last five years, remains underappreciated in academic discussions.

Future studies could use a similar "passive netnography" approach to expand the sample used in this exploratory investigation, or even follow the immersive 
DOI: 10.14807/ijmp.v5i3.171

procedures suggested by Kozinets (2010) by interviewing community members about their opinions and validating the findings with them later. Parallel communities have been formed at Quora.com based on questions such as "What does it take to be a successful entrepreneur?" (54 answers, 5000+ viewers, 200+ followers) or "What should you do if you want to be an entrepreneur, but have no background in business?" (44 answers, 19000+ viewers, nearly 400 followers). Filion's synthesis, enriched by some of the emerging categories found in this study, could be used to compare results among these communities and improve the overall value of the present findings.

\section{REFERENCES}

AMBLARD, H.; BERNOUX, P.; HERREROS, G.; LIVIAN, Y.F. (1996) Les nouvelles approches sociologiques des organisations, Seuil.

BEAVEN, Z.; LAWS, C. (2007). Never Let Me Down Again: Loyal customer attitudes towards ticket distribution channels for live music events: a netnographic exploration of the US leg of the Depeche Mode 2005-2006 World Tour. Managing Leisure, v. 12, n. 2, p. 120-142.

BRUYAT, C. (1993), Création d'entreprise: contributions épistémologiques et modélisation, Thèse pour le doctorat en sciences de gestion, Université de Grenoble II, octobre.

BROWN, S.; SHERRY JR., J. F.; KOZINETS, R. V. (2003). Teaching Old Brands New Tricks: Retro Branding and the Revival of Brand Meaning. Journal Of Marketing, v. 67, n. 3, p. 19-33.

BYGRAVGE W. D.; Hofer C. W. (1991) Theorizing about entrepreneurship. Entrepreneurship Theory and Practice. Winter, p. 13-22.

CARLAND, J. W.; HOY, F.; CARLAND, J. A. C. (1988) Who Is an Entrepreneur? Is the Question Worth Asking?, American Journal of Small Business, Spring, p. 3339.

COLE, A. H. (1942) Entrepreneurship as an Area of Research. The Task of Economic History. Supplement to Journal of Economic History, n. 2, p. 118-126.

COLE, A. H. (1946) An Approach to the Study of Entrepreneurship: A Tribute to Edwin F. Gay. The Journal of Economic History. Supplement VI. The Tasks of Economic History : 1-15. Reproduced in Aitken, H.G.J. (Ed.) (1965) Explorations in Enterprise. Cambridge, Mass. Harvard University Press: p. 30-44.

COLLINS, O. F., MOORE, D. G. (1970) The Organization Makers: A Behavioral Study of Independent Entrepreneurs. New York: Appleton-Century-Crofts.

FAYOLLE, A. (2001) D'une approche typologique de l'entrepreneuriat chez les ingénieurs à la reconstitution d'itinéraires d'ingénieurs entrepreneurs. Revue de l'Entrepreneuriat, v. 1, n. 1.

FILION, L. J. (1998) Entrepreneurship, entrepreneurs and small business ownermanagers. Published in: Julien, P.A. (Ed.) (1998) The Sate of the Art in Small 
Business and Entrepreneurship. Chapter 4. London: Avebury, p. 117-149, p. 428440.

FILION, L. J. (2000) Entrepreneurial typologies : are they really useful? In Brauchlin E., Pichler, J.H. (Eds) (2000) Unternehmer und Unternehmens-perspektiven für Klein- und Mittelunternehmen, Festschrift für Hans Jobst Pleitner, Duncker \& Humblot, Berlin/ St. Gallen: p. 163-172.

FILION, L. J. (1991) Vision et relations: Clefs du succès de l'entrepreneur - Les Éditions de l'Entrepreneur, Montreal, Canada.

GARTNER, W. B. (1988). Who is an entrepreneur? is the wrong question. American Journal of Small Business, Spring, p.11-32.

HO, P.; BARNES, L. (2012). An Examination of the Traits of Successful Entrepreneurs in Hong Kong: The PAST Model. Journal of Modern Accounting and Auditing, v. 8, n. 8, p. 1237-1245.

JULIEN P. A.; MARCHESNAY, M. (1996). L'entrepreneuriat. Economica. Collection gestion poche.

JULIEN, P. A., MARCHESNAY, M. (1987) La petite entreprise. Paris: Vuibert. KOZINETS, R. V. (2010). Netnography: doing ethnographic research online. Los Angeles, Calif.: SAGE.

KOZINETS, R. (2002). The field behind the screen: using netnography for marketing research in online communities. Journal of Marketing Research, v. 39, p. 61-72 LAFUENTE, A.; SALAS, V. (1989) Types of Entrepreneurs and Firms: the Case of New Spanish Firms. Strategic Management Journal, v. 10, p. 17-30.

LAUFER, J. C. (1975) Comment on devient entrepreneur. Revue française de gestion, nov : 18-29.

LE MAROIS, H. (1985), Entrepreneur a-t-il un féminin ?, Cahier de Recherche de Lille, p.10.

MARCHESNAY, M. (1998) Confidence and Types of Entrepreneurs. Published in: Pleitner, H.J. Renaissance of SMEs in a Globalized Economy. St-Gall: Verlag KMU/HSG: p. 545-556.

MILES, R.; SNOW, C.C. (1978) Organization Strategy, Structure and Process. New York: McGraw-Hill.

MOROZ, P. W.; HINDLE, K. (2012). Entrepreneurship as a process: Toward harmonizing multiple perspectives. Entrepreneurship Theory and Practice, v. 36, n. 4, p. 781-818.

OMRANE, A.; FAYOLLE, A. (2011). Entrepreneurial competencies and entrepreneurial process: a dynamic approach. International Journal of Business and Globalisation, v. 6, n. 2, p. 136-153.

PERKINS, A. (2010). Identification in Popular Music: A Netnographic Exploration of Online Fan Communities. Proceedings of the Australian and New Zealand Marketing Academy Conference. Available at http://anzmac2010.org/proceedings/pdf/anzmac10Final00030.pdf 
SHAPERO, A. (1975). The displaced, uncomfortable entrepreneur, Psychology Today, v. 9, n. 6, p.83-88.

SMITH, N. R. (1967) The Entrepreneur and His Firm: The Relationship between Type of Man and Type of Company. Bureau of Business Research, East Lansing, Michigan: Michigan State University Press.

VERSTRAETE, T. (2002). Essai sur la singularité de l'entrepreneuriat comme domaine de recherche, Les éditions l'ADREG.

VERSTRAETE, T.; JOUISON-LAFFITTE, E. (2011). A business model for entrepreneurship. Edward Elgar Publishing.

VESPER, K. H. (1980) New Venture Strategies. Englewood Cliffs, N.J.: Prentice Hall. 